\title{
Promoting Student Voice and Choice: Examples from a Secondary EL Classroom Project
}

EMILY SUH

Texas State University

LISA HOFFMAN

Indiana University Southeast

DONNA ALBRECHT

Indiana University Southeast

SCOTT WADE

Jefferson County Public Schools

\begin{abstract}
A creative reflection project was designed and implemented for emerging multilingual students (EMS) in a newcomer high school class using instructional strategies which are often reserved for classes with gifted students. The project was designed around two principles embodied in high ability curriculum design positing that emergent multilingual students: 1) have the potential for high abilities and talents, and 2) invoke their own agency to show their learning. This article considers connections between instructional strategies used by English as a new language learning specialists and gifted/high ability education specialists in this high school newcomer program. The resulting project that focused on student assets was aligned with the English language proficiency standards of the WIDA framework to support instructional differentiation and assessment. This article discusses the successes and struggles that came from implementing this project with high school emerging multilingual students. The article shares the materials created for this unit as well as considerations for other educators who might consider adapting or implementing a similar project.
\end{abstract}

Keywords: newcomer, high ability, gifted, WIDA, choice menu, high school multilingual 


\section{Introduction}

Critical thinking skills, creative application of knowledge, and the development of selfexpression are recognized as essential priorities of modern schooling (Wiggins and McTighe, 2005). Yet educators of multilingual students--ourselves included--are susceptible to a common disconnect between theory and practice. While educators of emerging multilingual students agree that students have a wide range of skills and can use their strengths to demonstrate their learning, many educators believe that teaching English language learners requires developmental language teaching (i.e., grammar drills, worksheets, basic skills) before teaching higher levels of content and thinking (Sparks, 2015). Simultaneously, the demands of supporting students in developing English proficiency can leave teachers "in a rut" of prescriptive or uncreative instructional practices, particularly since teachers may lack access to quality training on building creative and critical thinking skills among students who are also developing language proficiency (Samson \& Collins, 2012; Walqui \& van Lier, 2010). One underutilized source of knowledge and experience in nurturing creative and critical thinking skills is the field of gifted and talented (or "high ability") education. This article describes a creative reflection project designed for EMS educators to incorporate instructional strategies that have been informed by practices in gifted education. A collaborative teacher-researcher team approached this action research project with the following guiding questions: Can asset-based instructional materials used with high ability students be successfully adapted for a high school classroom of newcomer emerging bilingual students? How can teachers prioritize students' agency utilizing the tools of the WIDA organization to support language development and assessment?

The research team approached these questions by engaging in action research to design a classroom project for high school students at various language proficiency levels in a newcomer 
classroom. The team used a variety of scaffolding steps and created a menu of assessment options and a WIDA-aligned rubric. Such open-ended instructional materials, while familiar to teachers of identified gifted/talented/high ability students, may be unfamiliar or intimidating for English as a new language (ENL) teachers who are often not trained to use such strategies. This article includes these materials and the results of this practitioner research study to encourage other ENL educators to consider collaborating with educators in other fields--such as high ability/gifted and talented specialists--in order to elevate the voices and choices of emergent multilingual students and to highlight the intersection between these two fields.

\section{Literature Review}

Research in TESOL has expanded significantly over the past two decades. One example of this is seminal research by Thomas and Collier (1997) discussing the benefits of bilingualism and biliteracy for students' cognitive abilities. Today, TESOL professionals work with many students who, like the participants in our study, are often multilingual before they even begin learning English. Thomas and Collier's (1997) findings about the benefits of bilingualism are still supported by more recent research and extend the benefits of multilingualism over monolingualism beyond cross-cultural communication to greater levels of executive function, attention, and task-switching (Bialystok, Craik \& Luk, 2012; Marian \& Shook, 2012).

There is growing evidence that emerging multilingual students (EMS) make greater gains when high expectations, acceleration of learning, agency, and their emerging multilingualism are leveraged in the classroom. This shift to an asset-based approach to teaching acknowledges these students as emerging multilinguals capable of linguistic and academic success through scaffolded acceleration. The basis of this shift starts with acknowledging the students' assets relevant to their classroom learning and having high expectations for what they can accomplish 
(Albrecht, 2018; Hausman, Teemant \& Kigamwa, 2016; Walqui \& van Lier, 2008; Cummins, 2000).

Educators need support to understand how to view and utilize students' emerging bilingualism and their cultural diversity as assets in the classroom and factors that can enrich learning for all students (Goodwin \& Hein, 2016). In emerging work by the Indiana High Ability, English Learner Collaborative, results of combining pedagogy and strategies from the Gifted and Talented/High Ability field and the TESOL field are showing promise in providing the structure and support that teachers need (Albrecht, 2018). The Framework for Teaching and Learning in the High Ability/English Learner Collaborative Classroom (Albrecht, 2019a)

highlights the intersections between GT/HA and TESOL pedagogy and outlines several areas of overlap relevant to the present study. In a state-wide survey in Indiana, Albrecht (2019b) found that the majority of teachers who are trained to teach Gifted and Talented/High Ability students are not trained to work with English learning students. On the other hand, 77 percent of teachers in the study who are trained and licensed to teach English as a New Language (ENL) were not trained in gifted pedagogy. The present study explores the connection between these two fields for the purpose of accelerating English learner agency in their own learning.

Approaches to teaching and learning in the field of gifted education focus on developing students' strengths, assets, agency, and active participation in their own learning (Sousa, 2009; Wiggins \& McTighe, 2005; Winebrenner \& Brulles, 2012). Renzulli (2005) asserts that the gifted field has been a laboratory for innovation in education that has contributed to changes in the general education realm. In the same article, Renzulli argues that educators should apply gifted pedagogy to the development of talent in all students. While not going to that extent, the State of Indiana has expanded the definition of giftedness to include a broader range of high 
ability students and uses the term High Ability in legal code (Indiana Association for the Gifted, n.d.). The present study acknowledges the cognitive value of multilingualism and explores the application of strategies from gifted education to enhance and accelerate the potential of emerging multilingual students' abilities.

The move away from the role of teacher as the provider of knowledge to the facilitator of learning in the GT/HA world emphasizes the quest for deeper learning and understanding (Burns, Darling-Hammond, \& Scott, 2019; Renzulli, 2005). The literature in this field reflects the need to provide gifted learners with an environment for developing self-advocacy skills and self-regulatory abilities (Neihart, 2015; Reis \& Renzulli, 2003; Sousa, 2009). These pedagogical approaches to teaching and learning found in the GT/HA field can be effectively applied to all learners to enhance their critical and creative thinking, improve their communication skills, and demonstrate their learning through authentic, individualized assessments (Burns, DarlingHammond, \& Scott, 2019; Renzulli, 2005). Renzulli (2013) notes, "If persons involved in inductive learning experiences are given some choice in the domains and activities in which they are engaged, and if present experience is directed toward realistic and personalized goals, this type of learning creates its own relevancy and meaningfulness" (p. 232).

The TESOL field also advocates for viewing student learning from the perspective of what students can do rather than what deficits they have (WIDA, 2019). Multilingual learners' languages and cultures are valuable resources to be leveraged for schooling and classroom life; leveraging these assets and challenging biases help develop multilingual learners' independence and encourage their agency in learning (Kaul, 2019; Little, Dam, \& Legenhausen, 2017; Nieto \& Bode, 2018; Perley, 2011). The GT/HA field can lend pedagogical and curricular structures to 
TESOL practices that promote deeper learning and develop greater independence in student learning.

Several aspects of GT/HA instruction have great potential to inform curricular choices when working with multilingual students. This includes curriculum development processes which focus on learning as an inductive process of inquiry and discovery. Some of the relevant components of GT/HA curriculum design include: providing real world application of learning and authentic content; creating opportunities for student directed learning; creating a global perspective and using culturally relevant resources; providing opportunities for issue-related exploration; and promoting student choice and agency (National Association for Gifted Children, 2010; Sousa, 2009; Winebrenner \& Brulles, 2012).

Another focus of gifted education research that is relevant to this study is the need to advance concepts with greater depth. This includes the use of rigorous content, higher order thinking, and high expectations for all learners. In order to accomplish these goals, teachers need to facilitate student autonomy of their learning. Some strategies that foster such metacognitive development include pre-assessment to determine prior knowledge, use of advance organizers, and developing self-regulated learning processes using think aloud, graphic organizers, and self-reflection (Barfurth et al., 2009; Dymock \& Nicholson, 2010; Santa \& Havens, 2012; Sousa, 2009).

Taking an alternative approach to assessment is another GT/HA practice that is beneficial to EL students. Particularly advantageous components of this element include performancebased assessment; choice in demonstration of knowledge; student self-assessment, goal setting and monitoring; use of creativity and the creative process; and the use of rubrics that focus on 
learning and language development separately (Guskey \& Jung, 2013; National Association for Gifted Children, 2010; Tomlinson \& Moon, 2013; WineBrenner \& Brulles, 2012).

Developing rich language ability across contexts is a characteristic of GT/HA education that is equally important in the TESOL field (Santa \& Havens, 2012; Sousa, 2012; Winebrenner \& Brulles, 2012). GT/HA curriculum often looks at the richness of words, etymology, expression and manipulation of words, and other aspects of the study of words. Additionally, it extends language use to advanced activities such as writing journals, literature circles, writer's workshops, and reasoning and persuasive activities such as Socratic seminars (Sousa, 2012). GT/HA students are encouraged to use prior knowledge and experience, use cognitive processing with the text to develop concepts, take more time for processing and development of ideas and concepts, encounter and use increasingly difficult vocabulary and concepts, pursue ideas in the direction that their interests take them, anticipate the meaning of text based on visual clues, and so on (Vosslamber, 2002). Using these approaches of scaffolded support based on students' English language proficiency levels not only shows belief in their capability to do more challenging work, it also provides them with richer language samples to enhance their language development. For emerging multilingual students, support and scaffolding for their language proficiency levels to enable them to engage in higher order thinking on challenging content is part of differentiation in the inclusive classroom. Metalinguistic development, including language self-correction and thinking about language, is also vital for EMS (Baker, et al, 2014; Gibbons, 2009; Gottlieb, 2016; Teemant, 2015; Pereira \& De Oliveira, 2015; Walqui \& van Lier, 2010; WIDA, 2019).

Albrecht (2019a) outlines several ways that educators can work as facilitators of learning to promote emerging multilingual student agency, including the following: 
- Providing highly challenging learning activities with support for language proficiency levels by using the WIDA Framework to differentiate - i.e. creating Model Performance Indicators;

- Providing multiple points of entry to robust tasks through scaffolding and choice;

- Utilizing learning activities that promote multiple modalities of expression with tools such as graphic organizers, visuals, word walls, sentence frames, personal dictionaries, peer interaction in academic conversations, and translanguaging;

- Focusing on academic language use (writing, speaking) in the process and products of learning.

This article outlines one approach to applying these strategies and GT/HA pedagogy in order to enhance the language development and agency-enactment of high school emerging multilingual students.

\section{Methodology}

Through action research (Mills, 2003), the present study examined how teachers can prioritize students' agency through asset-based instructional methods. As a means of participatory and collaborative research to solve a real-world problem, action research was appropriate for exploring how to shift towards assets-based instructional materials in one newcomer emerging multilingual classroom.

\section{Methods and Data Collection}

This action research project was undertaken during the spring 2018 semester at a newcomer high school. The teacher-educators volunteered in the teacher-practitioner's classroom weekly. Data were collected by the first and second author, who kept field notes based on their observations and volunteering in the classroom during their weekly two-hour visits to the class in 
which the action research project occurred and additional observations in the advanced ESL class, which was taught by the same classroom teacher and included many of the same students. During the course of the semester, the teacher-educators spent over 60 hours in the teacherpractitioner's classroom. Data included photographs of student work, field notes from observations and volunteering in the classroom.

\section{Research Site}

New Arrivals School (NAS; all names are pseudonyms) provides linguistic, academic and social/emotional support for recent-arrival immigrant students in grades six through ten. NAS provides intensive English language support through sheltered instruction for 1-3 semesters, after which students transition to a mainstream secondary school where they will continue to receive EMS support. At the time of this research collaboration, NAS served approximately 520 students from a wide variety of language backgrounds who entered the district with limited English proficiency. The five languages with the most student speakers were Spanish (57\% of the total school population), Swahili (18\%), Somali (9\%), Kiryarwanda (7\%), and Arabic (5\%). Other languages included Nepali, Haitian Creole, Mai Mai, Vietnamese, Russian, Portuguese, and Burmese.

The research site was the advanced English classroom where one of the research collaborators serves as lead teacher. The class consisted of 28 ninth and tenth graders, ranging in age from 16 to 19 years of age, from Cuba, Mexico, Gambia, Senegal, Syria, Mauritania, Uganda, Congo, Somalia, Guatemala, Yemen, and Venezuela. Like the rest of the school, Spanish speakers (mostly from Cuba) made up the largest portion of the class.

Because of its student population, NAS had previously hosted an annual "Global Homecoming" event for nationality groups to share their culture in a gymnasium decorated with 
student-made flags and posters and hosting traditional dances and food tastings. As one teacher explained, "Global Homecoming at the [New Arrivals] has traditionally been a chance for nationality groups to show off their culture - posters, flags, food. It was mostly just fun.” However, the school's administration decided to connect the celebration to an academically oriented project in order to prepare students for future group work and problem solving tasks. The result was a schoolwide homecoming project exploring the essential question, "What is home?" Students worked on their projects in weekly meetings over the course of the spring semester in anticipation of a culminating school-wide presentation. Teacher educators were volunteering in the school at the time and partnered with a classroom teacher in a research collaboration to explore instructional opportunities posed by this schoolwide project. All the researchers noted the complexity of posing the question "What is home?" to immigrant adolescents, most of whom came from refugee backgrounds with various levels of trauma associated with the conditions which required them to leave their countries of origin. The project also included several opportunities for both creative and critical thinking as well as student selfexpression.

\section{Data Analysis}

Qualitative data analysis for action research includes description of "what is happening and to understand the effects of some educational intervention" (Mills, 2003, p. 5). Members of the research team frequently met to discuss and reflect upon the class and to prepare for future lessons. The teacher-educators' memos on these meetings were also added to the data collected, which were analyzed by the research team first for ways to improve students' comprehension of the "What is Home?" project and second for evidence of prioritizing students' agency within the WIDA framework for language development and assessment. The resulting project 
implementation evolved in response to effort to support students' understanding of and agency within the project.

\section{Results: Project Implementation}

This project posed an exciting but intimidating challenge not only because of language development but also because most students had no prior experience with multi-week projects or creative classroom projects. Students initially expressed concern over how to begin such a large project. These findings were consistent with literature suggesting that students may initially be overwhelmed or reluctant to engage in student-designed projects when they feel the teacher's expectations are unclear (Furnham \& Marks, 2013; DeRoma, Martin \& Kessler, 2003). These initial feelings of confusion may have been amplified for the newcomer students who may not have had previous experience with student-directed learning experiences. As a result, the classroom teacher created the structure for the unit through a multiple-class plan involving seven steps which intentionally scaffolded students' exploration of the theme, "What is home?"

The research team recognized that some structure would be necessary for students to complete their first lengthy open-ended project. Likewise, some scaffolding would be needed for students to meet the linguistic challenges posed by the prompt. The researchers who volunteered in the class worked closely with the teacher-collaborator to prepare additional scaffolding and to respond to issues which emerged as students grappled with both the content (i.e., emotional reactions, decisions about how much personal story to share, what products to create) and the language required to complete the project. From the outset, the research team was committed to allowing students as much freedom as possible to assert their agency and make choices about how they wanted to complete this school-wide project. As a result of weekly volunteering in the class, the teacher educators were privileged to observe students as they exercised their 
developing independence and conceptualized ways to showcase their artistic and linguistic abilities. Our availability allowed students to seek us out as they felt necessary and comfortable but still centered the students as the experts on the topic and the tasks. Several students, for example, created paintings or sketches. The research team also observed and assisted with vocabulary or acted as sounding boards for the students who wrote letters in English to family and friends about their memories of home.

\section{Step 1: Word List Brainstorm}

Pairs of students shared a piece of poster paper and each generated a personal list of ten words in response to the question, "What is home?" (see Figure 1). They discussed their lists and then each student chose four most important aspects of home.

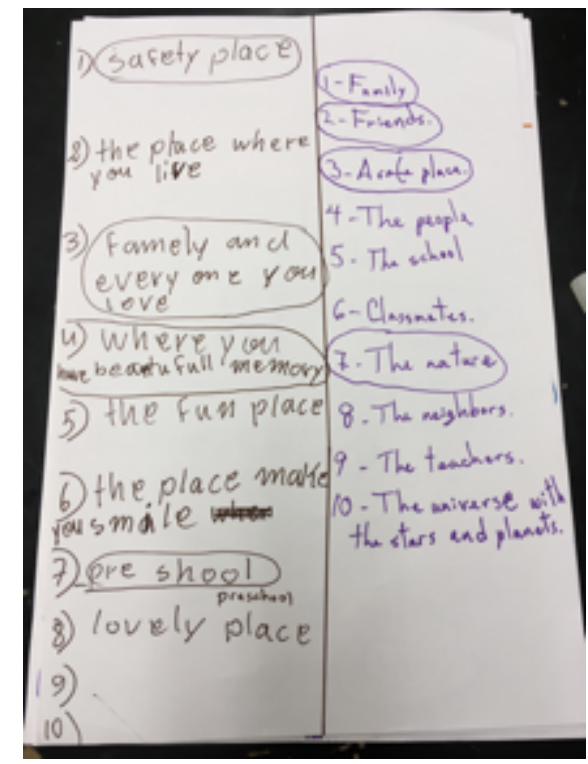

Figure 1: Word List Brainstorm of Phrases Related to Home

\section{Step 2: 4-Corners Poster}

From their four most important aspects, each student created a 4-corners poster which included a different word in each corner and an image or short text to connect their chosen words to specific images in their minds (see Figure 2). 


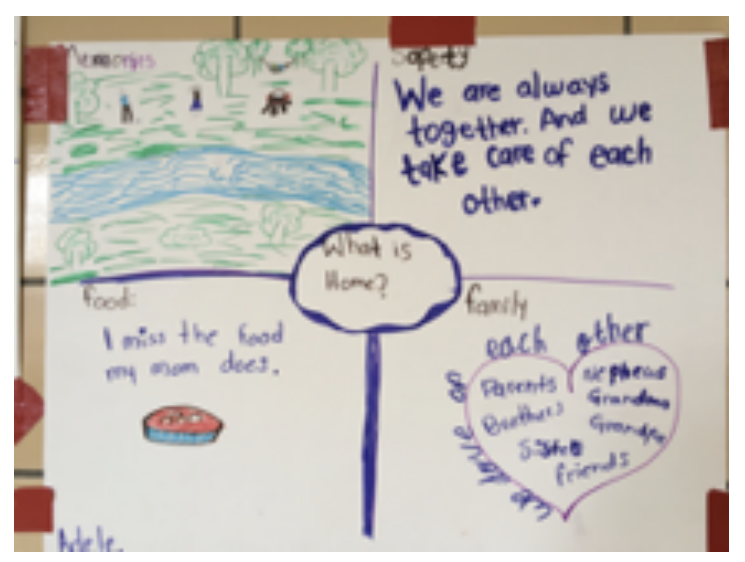

Figure 2: 4-Corners Poster of Phrases and Images Invoking Home

After students completed their 4-Corners posters, students and teachers left sticky notes for the student authors to elicit deeper explanations and connections between poster topics and the overarching question, "What is home?" (see Figure 3). For example, if a poster described food, a response might ask "What kinds of food did you eat?"

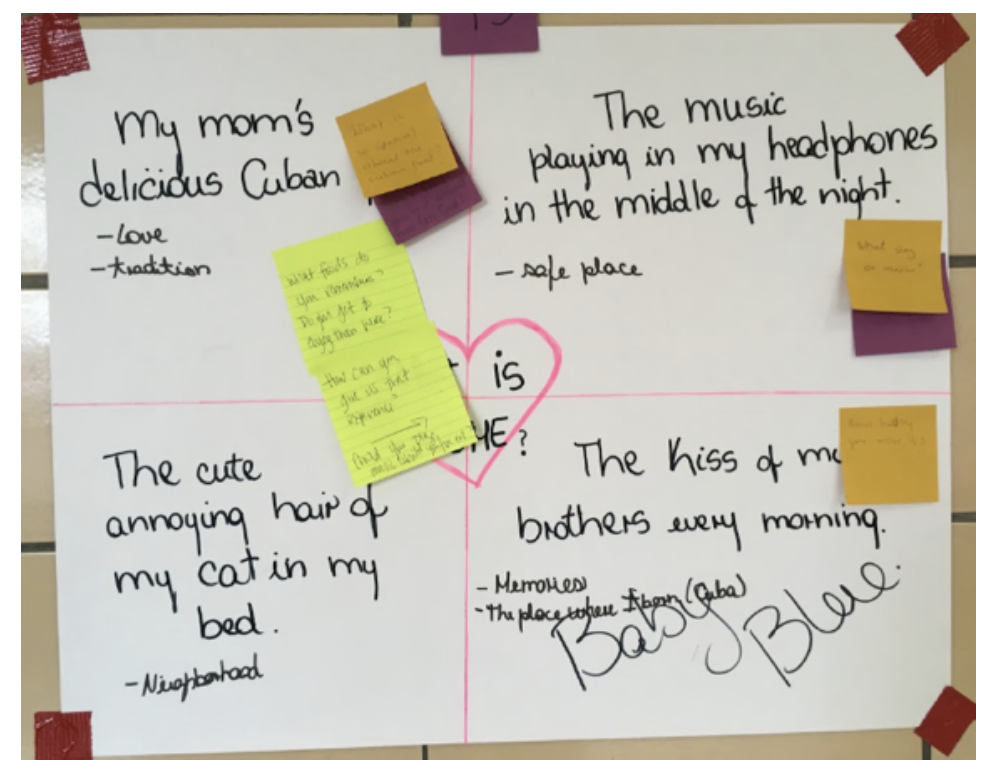

Figure 3: 4-Corners Responses

To help students draw connections between their experiences of home, the classroom teacher created several posters listing the themes found on the posters (Figure 4). Students added their names or nicknames to the posters to indicate themes which represented home to them 
personally. The posters allowed students from different countries to relate and compare shared themes of home. For example, in Figure 4, students from four different countries could begin a conversation about how school represented home to them.

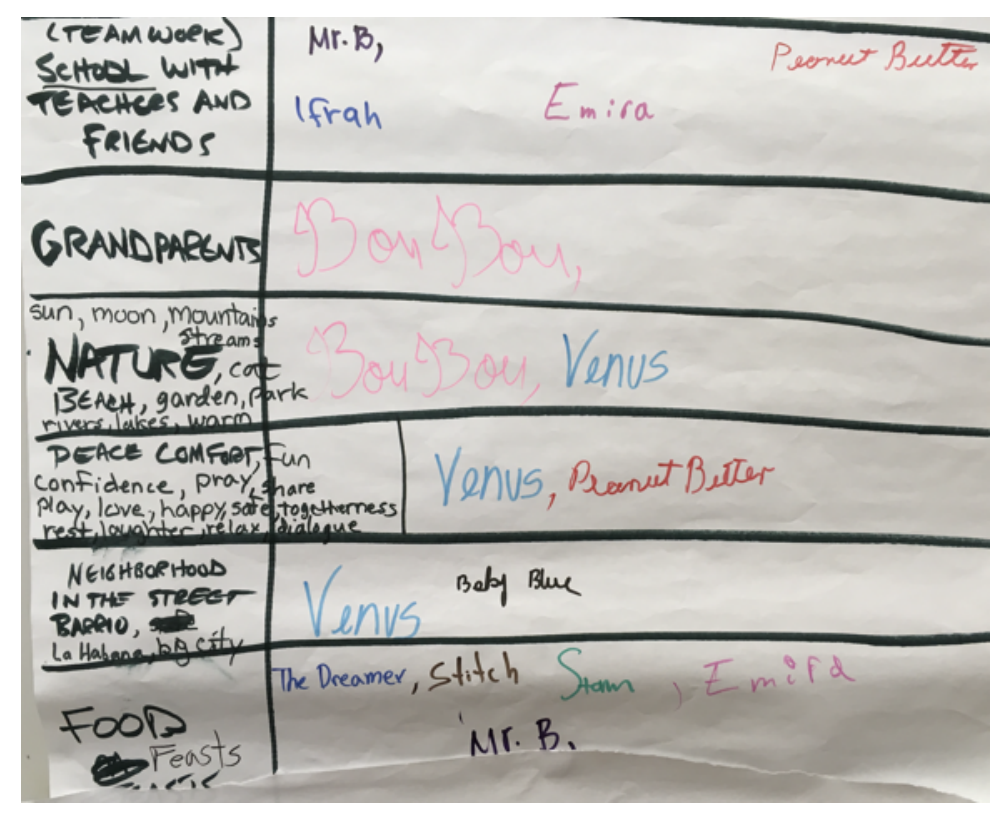

Figure 4: Students' Shared Themes

\section{Step 3: Project Choices}

The teacher educators collaborated with the classroom teacher to create a choice menu to reiterate the school's stated purpose of the project and to offer examples of student product outcomes for the unit. (See Appendix A). The choice menu's 25 options were equally divided into performance options (further separated into visual art performance and oral performance) and writing options, with one extra option for writing. Students were required to choose at least one performance and one writing option. All option types included the option for another type of performance with teacher approval. After receiving the choice menus, students identified their top three project choices on large papers (Figure 5). This means of sharing allowed students to see each other's plans, fostering collaboration and encouragement among the students across language groups. Students informally discussed with each other as they wrote out their options. 


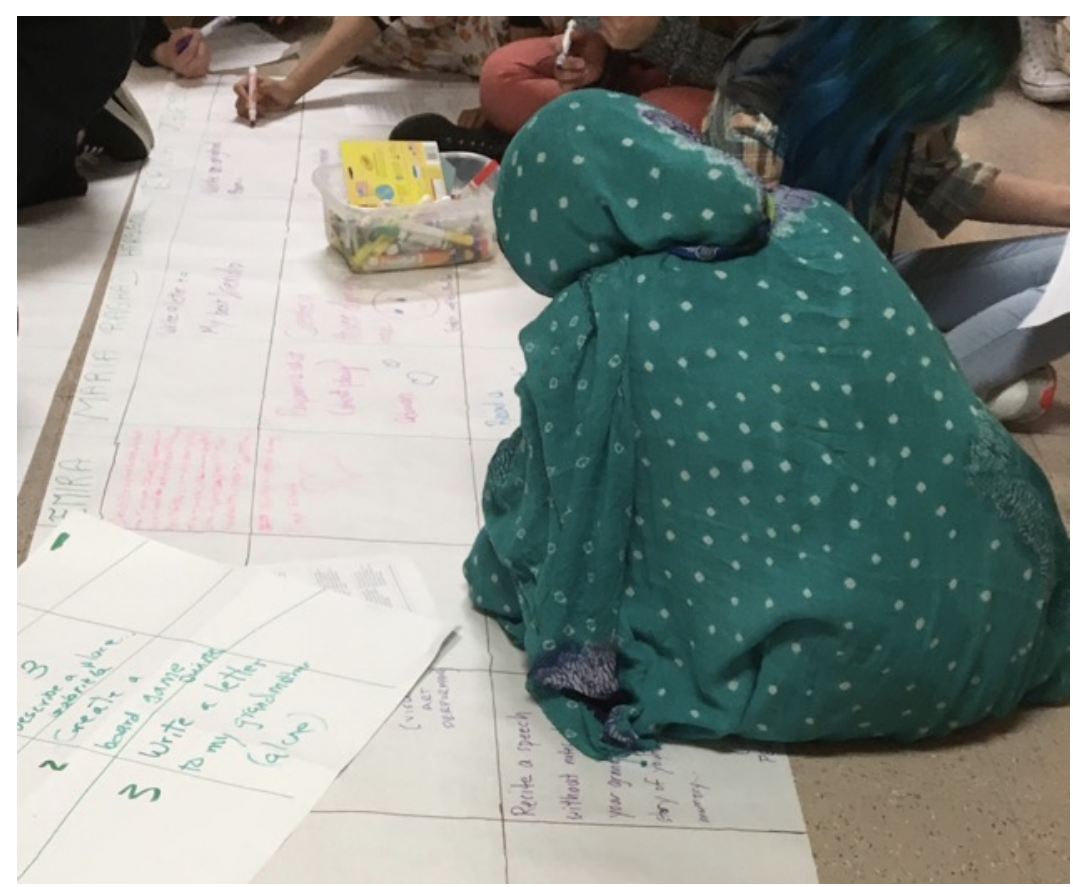

Figure 5: Creating Student Choice Plans

\section{Step 4: Choosing Project Options}

After creating their individual lists, students identified potential partners based on shared project interests (Figure 6). The classroom teacher felt that partnering based on project rather than conceptualization of home would encourage cross-language pairing, assuming that students who shared a similar vision of home would be from the same country or language background.

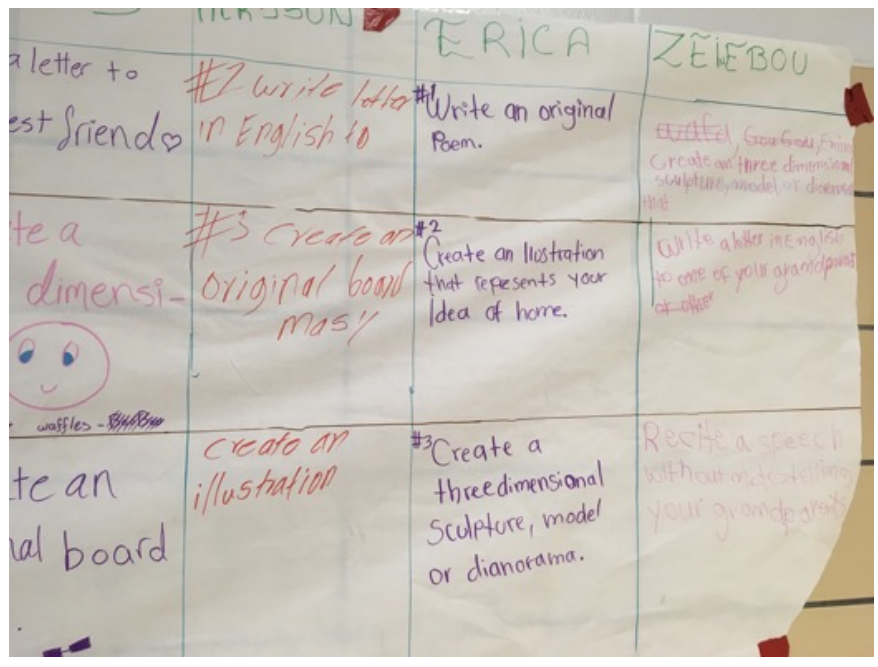

Figure 6: Planning Partnering for Project Creation 
Ultimately, students facilitated several collaborative projects, including a game, a documentary, and a painting. The painting was the only cross-language partnership, but the pairing between students from Yemen and Cuba seemed to foster a new relationship as the artists had been friendly but not friends prior to their shared painting of an evening beach scene (Figure 7).

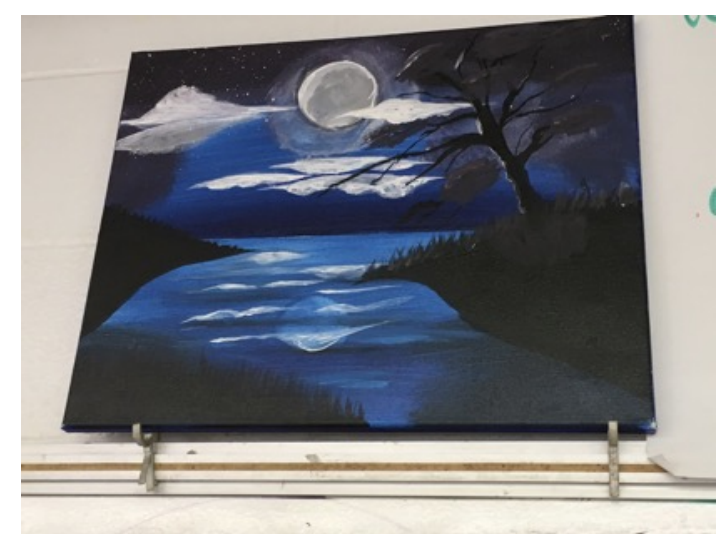

Figure 7: Shared Visual Performance

Visual performance options. Performance options included live options (i.e., a pantomime or dance) as well as options which could be viewed after the performance (i.e., an illustration, a sculpture, or a board game). This range of performance options gave students the freedom to choose the amount and type of language they wanted to use to present their meaning of home. None of the students submitted a live performance option, although one pair created a video about the meaning of home based upon interviews of school and community members. The project was inspired by their overlapping interests: one of the students expressed an interest in a future career as a reporter while the other enjoyed using technology.

The choice menu also included several visual options in order to honor the performances of students who felt reluctant to present orally or through an English medium. Several students created visual representations of home (see Figures 8 and 9). 


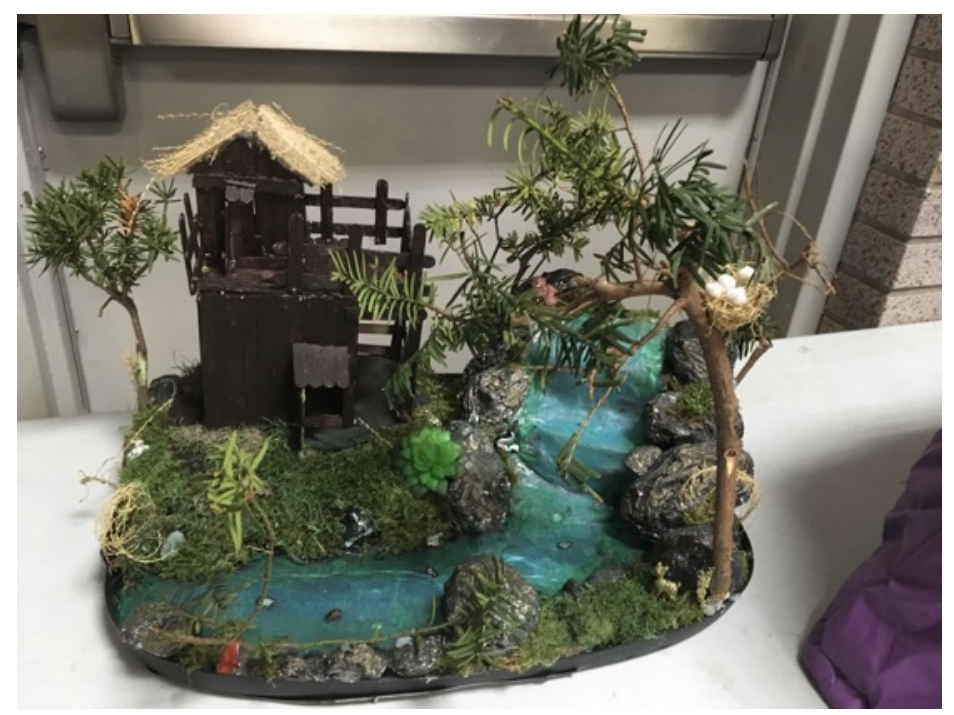

Figure 8: "Diorama of Home"

While many of the visuals represented physical locations which the students identified as reminding them of their homes (i.e., Figure 8), some of the images were more metaphorical in nature. Figure 9, for example, was drawn by a student after reading Maya Angelou's "I Know Why the Caged Bird Sings." The student, whose father had arranged a marriage for her against her will, identified strongly with the poem and described feeling trapped.

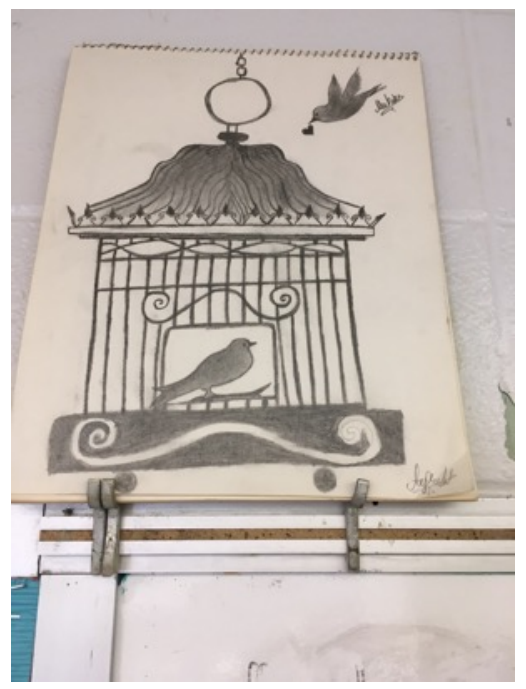

Figure 9: Drawing in Response to "I Know Why the Caged Bird Sings" 
Written performance options. Written options included a variety of genres, such as fictional stories, expository essays, original poetry/rap or script, comparative analysis, and description. Regardless of the genre, all but two options (song/rap and poetry) included a minimum page length ranging from one to three handwritten pages. The options allowed students choices in the level of personal experience they wished to share in their writing. For example, students could write a letter to a friend reliving a shared memory from home, but they also had the option to write about how a classroom community can start to feel like home. Options like the latter allowed students opportunities to participate even if they were uncomfortable writing about a previous home. Another option included writing about the evolving nature of the concept of home and specifically addressed moving from place to place. These options allowed students the freedom to discuss "home" as a physical place, an emotional connection, or something in between.

Student choice was particularly important for this group of newcomer students, many of whom had been forced to flee their homes for religious or political reasons. However, child and youth immigrants often have the least sense of agency in their migrations regardless of whether their migration may be considered voluntary, as they are rarely consulted on their feelings about migrating (Catalano, 2016). The provided written options attempted to honor the complex feelings these students may have held towards the notion of home and offer them a rhetorical space to explore those emotions to a degree of their choosing. The options also allowed learners control over the type of written language they would be producing. For example, students who wished to showcase their command of academic English and formal writing conventions could write a comparative analysis; however, students were also presented with several options that allowed them to convey feelings about home in a depth of their choosing through their Basic 
Interpersonal Communication Skills (Cummins, 1999). Thus, the writing options structured the assignment so that students could exercise their agency in terms of how and what they chose to share about the meaning of home. Many students chose to write letters home to friends or family about shared memories. The letters were displayed during the "Global Homecoming Celebration" event.

\section{Step 5: Scaffolding through Deadlines and Incentives}

As a part of the scaffolding, the classroom teacher established a series of deadlines and incentives for completing the projects. These deadlines were posted around the classroom and were regularly referenced as the classroom teacher introduced weekly tasks.

\section{Step 6: Student Reflection Presentations}

After creating their projects, students wrote reflections discussing their initial thoughts about "what is home," their processes for choosing options, and what they learned through completing the project with products of their choice. The students then practiced oral expression of their reflections. The teacher video-recorded students' reflections, which they presented without notes, and the video exhibition of these spoken reflections also became part of the schoolwide event.

\section{Step 7: Assessment}

The research team also created assessment tools to assist the classroom teacher's implementation of the "What is Home?" unit in order to provide rigorous differentiated assessment and structure for students as they began their first self-directed learning experience. Based upon the WIDA CAN DO descriptors for grade band 9-12, the team created a Can Do rubric for the writing options. Like the WIDA descriptors, this rubric highlights different skills in the language functions of Recount, Explanation, and Argument, indicating what students can do 
in their writing at different proficiency levels. The tool mapped directly on to the existing WIDA framework, which was already used by NAS teachers. The teacher educators also created two separate assessments for students to self-assess their learning as demonstrated in each project design element (Appendix B) and to specifically assess students' written components (Appendix C).

Students were asked to identify with statements about their understanding of each project element on a scale ranging from "Design Element Not Met (the project has problems in one or more areas)" to "Includes Design Element Features (the project has the following strengths)." This rubric incorporated several "I can" statements which encouraged students to think about their linguistic and academic growth throughout the project. Because the unit was originally conceptualized by school administrators as a form of project based learning, the rubric was modeled after materials from the Buck Institute; however, the project diverged from several criteria of project based learning and is not described in this article as utilizing that teaching strategy. Guided by their responses to the project rubric, students completed these written reflective assessments about their learning from the project separate from the oral summaries they recorded.

\section{Discussion}

Can asset-based instructional materials used with high ability students be successfully adapted for a high school classroom of newcomer emerging bilingual students? How can teachers prioritize students' agency utilizing the tools of the WIDA organization to support language development and assessment? These questions guided the creation of materials for the Global Homecoming project and implementation of the creative process. This project demonstrates the benefits of teaching through GT/HA pedagogical strategies for newcomer 
English learners. The project's student choice menus and self-assessment tools, combined with intentional scaffolding, successfully promoted students' agency through research-supported language development and assessment. The project was successful at providing enough levels of scaffolding to allow students to complete their first open-ended project successfully.

A future theme such as "What is learning?" would allow students the same level of agency and engagement while presenting with less potential to invoke past trauma. Centralizing students' self-assessment through student use of the self-assessment tools in their project planning might also be helpful to guide their drafting and revision processes. Future projects could include students' self-assessment for reflecting back on their language use and development in order to set measurable goals for themselves in future projects. Encouraging students' self-reflection is an essential component to their agency development.

All but one student completed the unit with the class, producing at least two performance options. Each participant interpreted "home" to mean their country of birth. During the research team's observations, most student participants reported enjoying this project and being able to share artistic or written descriptions of places they loved. The notable exception was a student who reported distress over the topic and chose not to participate. This student moved to another class that was working on a project which allowed her to present compelling and powerful artwork (still associated with "home") but which did not require that she also discuss or write about her understanding of home. This student's experience raises a concern the research team had anticipated from the introduction of the project--that is, the complexities to consider when asking newcomer students to explore a sensitive concept such as "home." For the students at New Arrivals School, most of whom are from refugee backgrounds, the separation from their culture of birth (or culture of first relocation, for those raised in refugee camps) is temporally 
recent, emotionally raw, and/or surrounded by traumatic memories or associations. Granted, final anonymous reflections indicated that most students enjoyed both the process and the product of the "What is Home?" project. But such a topic carries an intrinsic risk of disturbing or even retraumatizing a student. Teachers interested in replicating such a project should choose their theme with sensitivity and respect. Remember the centrality of student agency, as well. This project was committed to elevating student voice and choice in an EMS classroom, and part of student agency is allowing students the right to push back against an assignment and engage as they feel comfortable.

\section{Implications}

Although this project was created with the assumption that emerging multilingual students have potential for high abilities and hidden talents, the authors understand that the field of gifted education has definitions and criteria for identifying students as high ability or gifted and talented. This article is not intended to minimize or challenge the work of gifted education research. However, the work contributes to discussions extending the recognition of multilingualism as an intellectual skill and encourages identification criteria to consider speed of language learning as an indicator of giftedness. The project also suggests a place for gifted and talented research in the professional development of EMS teachers--as well as the necessity of Second Language Acquisition and TESOL research and professional development about language learning in the training of high ability specialists. Both GT/HA teachers and EMS teachers have toolboxes of differentiation and scaffolding strategies that would be the envy of many other classroom teachers. For example, the WIDA framework provides one tool to support language and advanced content goals, and choice menus could be used by both GT/HA and EMS teachers committed to allowing students to use their own agency to show their learning. High 
ability education specialists and English language learning specialists should work together and share tools whenever possible for the benefit of emergent multilingual students.

Inquiries can be directed to Donna Albrecht: dalbrec@iu.edu

\section{ABOUT THE AUTHORS}

Emily Suh is an Assistant Professor in the Graduate Program of Developmental Education at Texas State University. Her research explores the intersection of multilingual students' language acquisition, literacy practices, and identity enactment in K-16 contexts. In 2018, she received the Dissertation Award from the American Association of Applied Linguistics.

Lisa Hoffman is Associate Professor and Director of Graduate Studies at the School of Education at Indiana University Southeast. Her research interests include teacher preparation for culturally and linguistically diverse classroom contexts, supporting multilingual student success in STEM fields, and gifted education opportunities for emerging multilingual students.

Donna Albrecht is Associate Professor, Coordinator of ENL/ESL, and Director of The New Neighbors Education Center at Indiana University Southeast. Donna has a Doctorate of Education in Educational Administration and Supervision, an Educational Specialist degree in School Superintendency, and a Master of Arts degree in Teaching English as a Foreign Language. Her research focuses on leadership and educator training in PK-12 ENL/ESL programs, and identifying and teaching English learners with gifts, talents and high abilities.

Scott Wade is a National Board-Certified teacher for Jefferson County Public Schools in Louisville, Kentucky. In 2014, Wade received the prestigious ExCel Award, and he now mentors National Board candidates. He leads his interdisciplinary team at the all ESL Newcomer Academy. He regularly partners with teachers and teacher-educators interested in supporting multilingual students in secondary schools. 


\section{References}

Albrecht, D.L. (2018). Suggestions for Identifying and Supporting English Learners with High Abilities, Gifts, and Talents. Paper provided to Indiana Department of Education and made available to Indiana schools. Retrieved from https://www.doe.in.gov/sites/default/files/highability/el-suggestions-identifying-andsupporting-els-high-abilities-2018.pdf

Albrecht, D.L. (2019a). Framework for teaching and learning in the high ability/English learner collaborative classroom. Manuscript in preparation.

Albrecht, D.L. (2019b). Identifying and Serving High Ability English Learners State Level Survey of Practices and Needs Assessment. Manuscript submitted for publication.

Baker, S., Lesaux, N., Jayanthi, M., Dimino, J., Proctor, C. P., Morris, J., Gersten, R., Haymond, K., Kieffer, M. J., Linan-Thompson, S., \& Newman-Gonchar, R. (2014). Teaching academic content and literacy to English learners in elementary and middle school (NCEE 2014-4012). Washington, DC: National Center for Education Evaluation and Regional Assistance (NCEE), Institute of Education Sciences, U.S. Department of Education. Retrieved from the NCEE website: http://ies.ed.gov/ncee/wwc/publications_reviews.aspx

Barfurth, M. A., Ritchie, K. C., Irving, J. A., \& Shore, B. M. (2009). A Metacognitive Portrait of Gifted Learners. In L.V. Shavinina (Ed.) International Handbook on Giftedness (pp. 397418). New York, NY: Springer. doi: 10.1007/978-1-4020-6162-2

Bialystok, E., Craik, F. I., \& Luk, G. (2012). Bilingualism: consequences for mind and brain. Trends in cognitive sciences, 16(4), 240-250. doi: 10.1016/j.tics.2012.03.001 
Burns, D., Darling-Hammond, L., Scott, C., Allbright, T., Carver-Thomas, D., Daramola, E. J ... \& Talbert, J. E. (2019). Closing the opportunity gap: How positive outlier districts in California are pursuing equitable access to deeper learning. Palo Alto, CA: Learning Policy Institute.

Catalano, T. (2016). Talking about global migration: Implications for language teaching. Bristol, U.K.: Multilingual Matters.

Cummins, J. (1999). BICS and CALP: Clarifying the distinction. Retrieved from ERIC database. (ED438551).

Cummins, J. (2000). Language, power, and pedagogy. Bilingual children in the crossfire. Multilingual Matters: Clevedon, England.

DeRoma, V. M., Martin, K. M., \& Kessler, M. L. (2003). The relationship between tolerance for ambiguity and need for course structure. Journal of Instructional Psychology, 30(2), 104109.

Dymock, S. \& Nicholson, T. (2010). "High 5!" Strategies to Enhance Comprehension of Expository Text. The Reading Teacher. 64(3), 166-178. doi:10.1598/RT.64.3.2

Furnham, A., \& Marks, J. (2013). Tolerance of ambiguity: A review of the recent literature. Psychology, 4(09), 717-728. doi: 10.4236/psych2013.49102

Gibbons, P. (2009). English Learners Academic Literacy and Thinking: Learning in the Challenge Zone. Portsmouth, NH. Heinemann.

Goodwin, B. \& Hein, H. (2016). Tap ELL's strength to spur success. EducationWeek. 73(5), 8283. Retrieved from ERIC database (EJ1089884). 
Gottlieb, M. (2016). Assessing English language learners: Bridges to educational equityconnecting academic language proficiency to student achievement $\left(2^{\text {nd }} e d.\right)$. Thousand Oaks, CA: Corwin.

Guskey, T. R., \& Jung, L. A. (2013). Answers to Essential Questions about Standards, Assessments, Grading, and Reporting. Thousand Oaks, CA: Corwin Press.

Hausman, C., Teemant, A. \& Kigamwa, J. (2016). The effects of higher order thinking on student achievement and English proficiency. INTESOL Journal. 13. Retrieved from http://journals.iupui.edu/index.php/intesol/article/view/21254

Indiana Association for the Gifted. (n.d.). What is "gifted" or "high ability". Retrieved from http://www.iag-online.org/community/Parents/page2/What\%20Is\%20Gifted\%20or\%20High\%20Ability/

Irby, B., \& Lara-Alecia, R. (1996). Attributes of Hispanic gifted bilingual students as perceived by bilingual educators in Texas. Sage Journal , 11, 120-143.Retrieved from https://ncela.ed.gov/files/rcd/BE021128/Attributes_of_Hispanic_Gifted.pdf Kaul, M. (2019). Keeping students at the center with culturally relevant performance assessments. Education Week. Retrieved from http://blogs.edweek.org/edweek/next_gen_learning/2019/05/keeping_students_at_the_c enter_with_culturally_relevant_performance_assessments.html Little, D, Dam, L \& Legenhausen, L. (2017). Language learner autonomy: theory, practice, and research. Bristol, U.K.: Multilingual Matters.

Marian, V., \& Shook, A. (2012). The cognitive benefits of being bilingual. Cerebrum : The Dana Forum on Brain Science, 13. Retrieved from https://www.ncbi.nlm.nih.gov/pmc/articles/PMC3583091/ 
Mills, G. E. (2003). Action research: A guide for the teacher researcher (2nd ed.). Upper Saddle River, NJ: Prentice Hall.

National Association for Gifted Children (2010). 2010 Pre-K-Grade 12 Gifted Programming Standards. Retrieved from http://www.nagc.org/sites/default/files/standards/K$12 \% 20$ programming $\% 20$ standards.pdf

Neihart, M. (2015). Services that meet social and emotional needs of gifted children. In R. Eckert \& J. Robins (Eds.). Designing Services and Programs for High-Ability Learners: A Guidebook for Gifted Education (2nd ed.) (pp. 122-135). Washington, D.C.: NAGC \& Corwin Press.

Neito, S. \& Bode, P. (2018). Affirming diversity: The sociopolitical context of multicultural education (7th ed.). New York, NY: Pearson.

Pereira, N. \& Gentry, M, (2013). A qualitative inquiry into the experiences of gifted English language learners in Midwestern, elementary schools. Journal for Advanced Academics, 24, 141-163. Retrieved from ERIC database (EJ1019383).

Perley, B. C. (2011). Language as an integrated cultural resource. In T. F. King (Ed.). $A$ companion to cultural resource management (pp. 203-220). Hoboken, NJ: Blackwell.

Reis, S.M. \& Renzulli, J. (2004). Current research on the social and emotional development of gifted and talented students: Good news and future possibilities. Psychology in the Schools, 41, 119 - 130. doi: 10.1002/pits.10144

Renzulli, J. (2005). Applying gifted education pedagogy to total talent development for all students. Theory Into Practice. 44(2). 80-89. doi: 10.1207/s15430421tip4402_2

Renzulli, J. (2013). Swimming upstream in a small river: Changing conceptions and practices about the development of giftedness. In M. A. Constas \& R. J. Sternberg (Eds.), 
Translating theory and research into educational practice: Developments in content domains, large scale reform, and intellectual capacity (pp. 223-254). New York: Routledge.

Samson, J.F. \& Collins, B.A. (2012). Preparing all teachers to meet the needs of English language learners: Applying research to policy and practice for teacher effectiveness. Washington, DC: Center for American Progress. Retrieved from ERIC database (ED535608).

Santa, C. M., Havens, L. T. \& Valdes, D.F.B. (2012). Project CRISS: Creating independence through student-owned strategies : helping teachers teach and learners learn. Dubuque, Iowa: Kendall Hunt Publishing Company.

Sousa, D.(2009). How the gifted brain learns. Thousand Oaks, CA: Corwin Press.

Sparks, S.D. (2015). ELL programs often focus on basic skills, not higher-order thinking, study finds. Education Week. Retrieved from http://blogs.edweek.org/edweek/learning-thelanguage/2015/11/ell_programs_often_focus_on_re.html

Teemant, A. (2015, May 15). Living critical sociocultural theory in classroom practice. International Conference on Language Teacher Education, Minneapolis, MN.

Thomas, W.P. \& Collier, V.P. (1997). School effectiveness for language minority students. National Clearinghouse for English Language Acquisition (NCELA) Resource Collection Series, No. 9, December 1997.

Tomlinson, C.A. \& Moon, T.R. (2013). Assessment and student success in a differentiated classroom. Alexandria, VA: ASCD. 
Van Lier, L. (2008). Agency in the classroom. In Lantolf, J. P., \& Poehner, M. E. (Eds.), Sociocultural theory and the teaching of second languages, (pp. 163-186). London: Equinox.

Vosslamber, A. (2002). Gifted readers: Who are they, and how can they be served in the classroom? Gifted Child Today, 25, 14-20.

Walqui, A., and van Lier, L. (2010). Scaffolding the academic success of adolescent English language learners: A pedagogy of promise. San Francisco, CA: WestEd.

WIDA (2019). WIDA guiding principles of language development. Board of Regents of the University of Wisconsin System. Retrieved from https://wida.wisc.edu/sites/default/files/resource/Guiding-Principles-of-LanguageDevelopment.pdf

Wiggins, G. \& McTighe, J.(2005). Understanding by Design: Expanded 2nd Edition. Upper Saddle River, NJ: Pearson.

Winebrenner, S. \& Brulles, D. (2012). Teaching Gifted Kids in Today's Classroom: Strategies and Techniques Every Teacher Can Use. Minneapolis, MN: Free Spirit Publishing Inc.

\section{Appendix A: Choice Menu What Is Home?}

Home is more than where you sleep at night. An English proverb says, "Home is where the heart is."

What is "home" to you? This project will allow you to explore the meaning of "home" in creative ways.

For this project, you will choose three ways to express what home is to you. You may choose from many forms of creative expression. Choose at least one writing option and at least one performance option.

All your work must be from your own original ideas. You must create your project yourself. You may work independently or with one partner.

Deadlines: Option 1 is due February 28. Option 2 is due March 7. Option 3 is due March 21. Performances in front of peers and teachers will be March 26-28. 
Performance Options: Choose at least one of these performance options.

\begin{tabular}{|c|c|c|c|c|c|}
\hline \multicolumn{6}{|c|}{ Visual Art Performance Options } \\
\hline $\begin{array}{l}\text { Create an } \\
\text { illustration } \\
\text { that } \\
\text { represents } \\
\text { your idea of } \\
\text { home. You } \\
\text { may use any } \\
\text { medium, } \\
\text { including } \\
\text { paint, } \\
\text { colored } \\
\text { pencils, } \\
\text { markers, or } \\
\text { cosmetics. }\end{array}$ & $\begin{array}{l}\text { Create a } \\
\text { three- } \\
\text { dimensional } \\
\text { sculpture, } \\
\text { model, or } \\
\text { diorama that } \\
\text { represents } \\
\text { your idea of } \\
\text { home. Use } \\
\text { any medium } \\
\text { or any } \\
\text { material } \\
\text { allowed in } \\
\text { school. }\end{array}$ & $\begin{array}{l}\text { Perform an } \\
\text { original } \\
\text { pantomime } \\
\text { (mime) you } \\
\text { created to } \\
\text { express your } \\
\text { understanding } \\
\text { of home. } \\
\text { Include } \\
\text { costumes. }\end{array}$ & $\begin{array}{l}\text { Perform an } \\
\text { original dance } \\
\text { you created to } \\
\text { represent } \\
\text { your idea of } \\
\text { home. }\end{array}$ & $\begin{array}{l}\text { Create an } \\
\text { original } \\
\text { board game } \\
\text { that shows } \\
\text { what you } \\
\text { think of } \\
\text { home. }\end{array}$ & $\begin{array}{l}\text { Think of } \\
\text { another } \\
\text { performance } \\
\text { of artistic } \\
\text { expression! } \\
\text { Get approval } \\
\text { from your } \\
\text { teacher } \\
\text { before you } \\
\text { begin. }\end{array}$ \\
\hline \multicolumn{6}{|c|}{ Oral Performance Options } \\
\hline $\begin{array}{l}\text { Sing a song } \\
\text { or perform a } \\
\text { rap you } \\
\text { created to } \\
\text { represent } \\
\text { home. This } \\
\text { must be an } \\
\text { original } \\
\text { song. }\end{array}$ & $\begin{array}{l}\text { Recite from } \\
\text { memory an } \\
\text { original } \\
\text { poem you } \\
\text { wrote about } \\
\text { your idea of } \\
\text { home. }\end{array}$ & $\begin{array}{l}\text { Perform a skit } \\
\text { (a short play) } \\
\text { you wrote to } \\
\text { express the } \\
\text { idea of home. }\end{array}$ & $\begin{array}{l}\text { Recite a } \\
\text { speech } \\
\text { without notes } \\
\text { telling your } \\
\text { grandparents } \\
\text { a story of } \\
\text { your favorite } \\
\text { memory } \\
\text { being with } \\
\text { them. }\end{array}$ & $\begin{array}{l}\text { Record a } \\
\text { "newscast" } \\
\text { video as if } \\
\text { you were } \\
\text { reporting } \\
\text { from a place } \\
\text { you consider } \\
\text { home. }\end{array}$ & $\begin{array}{l}\text { Think of } \\
\text { another oral } \\
\text { performance } \\
\text { option! Get } \\
\text { approval } \\
\text { from your } \\
\text { teacher } \\
\text { before you } \\
\text { begin. }\end{array}$ \\
\hline
\end{tabular}

Writing Options: Choose at least one of these writing options.

\begin{tabular}{|c|c|c|}
\hline $\begin{array}{l}\text { Write a letter in English to } \\
\text { one of your grandparents or } \\
\text { other relatives expressing } \\
\text { your understanding of home. } \\
\text { Include description of } \\
\text { specific places, specific } \\
\text { memories, specific people, } \\
\text { and dialogue. Minimum } \\
\text { length is one typed page or } \\
\text { two handwritten pages. }\end{array}$ & $\begin{array}{l}\text { Create a fictional story } \\
\text { expressing your } \\
\text { understanding of home. } \\
\text { Include description of specific } \\
\text { places, specific memories, } \\
\text { specific people, and dialogue. } \\
\text { Minimum length is one typed } \\
\text { page or two handwritten } \\
\text { pages. }\end{array}$ & $\begin{array}{l}\text { Describe a place in a } \\
\text { neighborhood that makes } \\
\text { you think of home, such as } \\
\text { a street corner, a park, } \\
\text { your grandmother's } \\
\text { garden, or another place. } \\
\text { Minimum length is one } \\
\text { typed page or two } \\
\text { handwritten pages. }\end{array}$ \\
\hline $\begin{array}{l}\text { Describe a place in nature } \\
\text { that makes you think of }\end{array}$ & $\begin{array}{l}\text { Write a comparative analysis } \\
\text { of what home means to you }\end{array}$ & $\begin{array}{l}\text { Create a play/skit for one } \\
\text { or two people, at least two }\end{array}$ \\
\hline
\end{tabular}




\begin{tabular}{|l|l|l|}
\hline $\begin{array}{l}\text { home, such as a riverside, a } \\
\text { forest walk, a beach beside } \\
\text { the ocean, a starry sky, or a } \\
\text { jungle. Minimum length is } \\
\text { one typed page or two } \\
\text { handwritten pages. }\end{array}$ & $\begin{array}{l}\text { in your home country and in } \\
\text { the United States. Include } \\
\text { description of specific places, } \\
\text { specific memories, specific } \\
\text { people, and dialogue. } \\
\text { Minimum length is one typed } \\
\text { page or two handwritten } \\
\text { pages. }\end{array}$ & $\begin{array}{l}\text { typed double-spaced pages } \\
\text { or three handwritten pages. }\end{array}$ \\
\hline $\begin{array}{l}\text { Write an original song or } \\
\text { rap. Minimum length is one } \\
\text { typed double-spaced page or } \\
\text { one handwritten single- } \\
\text { spaced page. (You may sing } \\
\text { the song or rap for a } \\
\text { performance choice.) The } \\
\text { song will have the theme of } \\
\text { what represents home to you. }\end{array}$ & $\begin{array}{l}\text { Write an original poem. } \\
\text { double-spaced page or one } \\
\text { handwritten single-spaced } \\
\text { page. (You may recite the } \\
\text { poem for a performance } \\
\text { choice.) The poem will have } \\
\text { the theme of what represents } \\
\text { home to you. }\end{array}$ & $\begin{array}{l}\text { Write a script for a news } \\
\text { feature or news story about } \\
\text { represents home to you. } \\
\text { typed page or two } \\
\text { handwritten pages. }\end{array}$ \\
\hline $\begin{array}{l}\text { Write a letter to your best } \\
\text { friend in your home country } \\
\text { describing a favorite } \\
\text { memory you had with them. } \\
\text { Minimum length is one } \\
\text { typed page or two } \\
\text { handwritten pages. }\end{array}$ & $\begin{array}{l}\text { Write an essay on the concept } \\
\text { that the idea of home changes } \\
\text { as you grow older and move } \\
\text { from place to place. } \\
\text { Minimum length is one typed } \\
\text { page or two handwritten } \\
\text { pages. }\end{array}$ & $\begin{array}{l}\text { Write an essay on the } \\
\text { concept that a certain } \\
\text { classroom during your } \\
\text { school day can start to feel } \\
\text { like home. Minimum } \\
\text { length is one typed page or } \\
\text { two handwritten pages. }\end{array}$ \\
\hline
\end{tabular}

Or, create another writing idea! Present your idea to the teacher for approval before you begin.

\section{Appendix B: Student Assessment [What is Home Project Rubric]}


"What is Home?" Project Rubric

\begin{tabular}{|c|c|c|c|}
\hline $\begin{array}{l}\text { Essential Project } \\
\text { Design Element }\end{array}$ & $\begin{array}{l}\text { Design Element Not Met } \\
\text { The project has problems in one or more } \\
\text { areas }\end{array}$ & $\begin{array}{l}\text { Needs More Work } \\
\text { The project has some strengths and some } \\
\text { areas for improvement }\end{array}$ & $\begin{array}{l}\text { Includes Design Element Features } \\
\text { The project has the following strengths }\end{array}$ \\
\hline $\begin{array}{l}\text { Understanding the } \\
\text { Project Goal }\end{array}$ & $\begin{array}{l}\text { - I cannot explain how my project } \\
\text { answers the question "What is Home?" } \\
\text { - I cannot use critical thinking skills to } \\
\text { create a project about the meaning of } \\
\text { "Home" } \\
\text { - I cannot work with my teammates, } \\
\text { listening to their ideas and cooperating } \\
\text { to create a project about the meaning of } \\
\text { "Home" }\end{array}$ & $\begin{array}{l}\text { - I need help to explain how my project } \\
\text { answers the question "What is Home?" } \\
\text { - I use some critical thinking or team } \\
\text { work skills to create a project about the } \\
\text { meaning of "Home" }\end{array}$ & $\begin{array}{l}\text { - I can explain how my project } \\
\text { answers the question "What is } \\
\text { Home?" } \\
\text { - I can use critical thinking AND/OR } \\
\text { team work skills to create a project } \\
\text { about the meaning of "Home" }\end{array}$ \\
\hline $\begin{array}{l}\text { Focusing on a } \\
\text { Challenging } \\
\text { Question }\end{array}$ & $\begin{array}{l}\text { - I do not answer the question "What is } \\
\text { home?" }\end{array}$ & $\begin{array}{l}\text { - I can answer the question, "What is } \\
\text { Home?" on a basic level } \\
\text { - In my project, I may have more than } \\
\text { one meaning of "Home" }\end{array}$ & $\begin{array}{l}\text { - I can answer the question, "What is } \\
\text { Home?" in a unique way that makes } \\
\text { people think } \\
\text { - In my project, I can explain one } \\
\text { meaning of home by focusing on one } \\
\text { aspect of what makes "Home" }\end{array}$ \\
\hline $\begin{array}{l}\text { Real-World } \\
\text { Context }\end{array}$ & $\begin{array}{l}\text { My project does not share my personal } \\
\text { interests with others } \\
\text { - My project is not interesting }\end{array}$ & $\begin{array}{l}\text { - I can share the meaning of "Home" } \\
\text { with materials or a presentation that is } \\
\text { informational but does not make a } \\
\text { personal connection }\end{array}$ & $\begin{array}{l}\text { - I can share the meaning of "Home" } \\
\text { with materials or a presentation that } \\
\text { is interesting and shares something } \\
\text { about myself }\end{array}$ \\
\hline Student-led Ideas & $\begin{array}{l}\text { I need my teacher or friends to tell me } \\
\text { how to create and complete my project }\end{array}$ & $\begin{array}{l}\text { I need my teacher or friends to tell me } \\
\text { how to create or complete part of my } \\
\text { project }\end{array}$ & $\begin{array}{l}\text { - I can create and complete my project } \\
\text { by developing my own ideas or } \\
\text { working together on my team's ideas }\end{array}$ \\
\hline Reflection & $\begin{array}{l}\text { - I do not think carefully about the } \\
\text { meaning of "Home" at each stage in my } \\
\text { project. }\end{array}$ & $\begin{array}{l}\text { - I think a little bit about the meaning of } \\
\text { "Home" as I work on my project } \\
\text { - I only change my thinking about the } \\
\text { meaning of "Home" a little as I work } \\
\text { on my project }\end{array}$ & $\begin{array}{l}\text { - I can think carefully about the } \\
\text { meaning of "Home" at each stage in } \\
\text { my project. }\end{array}$ \\
\hline
\end{tabular}

"What is Home?" Project Rubric

\begin{tabular}{|c|c|c|c|}
\hline & $\begin{array}{l}\text { - I do not change or think more deeply } \\
\text { about the meaning of "Home" as I } \\
\text { worked on my project } \\
\text { - My project may need some outside } \\
\text { information/research to make sense to } \\
\text { my audience }\end{array}$ & $\begin{array}{l}\text { I may have too much outside } \\
\text { information/research that is not } \\
\text { explained to my audience }\end{array}$ & $\begin{array}{l}\text { - I can change or think more deeply } \\
\text { about the meaning of "Home" as I } \\
\text { work on my project } \\
\text { - I can make a project that uses outside } \\
\text { information/evidence appropriately }\end{array}$ \\
\hline $\begin{array}{l}\text { Finished, Public } \\
\text { Product }\end{array}$ & $\begin{array}{l}\text { - I cannot explain the choices I made in } \\
\text { my project or what I did to make my } \\
\text { project } \\
\text { - I cannot explain what I learned about } \\
\text { "Home" to my audience }\end{array}$ & $\begin{array}{l}\text { - I can explain some of the choices I } \\
\text { made in my project or some of what I } \\
\text { did to make my project } \\
\text { - I need help to explain what I learned } \\
\text { about "Home" to my audience }\end{array}$ & $\begin{array}{l}\text { - I can explain the choices I made in } \\
\text { my project and what I did to make } \\
\text { my project } \\
\text { - I can explain what I learned about } \\
\text { "Home" to my audience }\end{array}$ \\
\hline $\begin{array}{l}\text { Project Sharing: } \\
\text { Speaking }\end{array}$ & $\begin{array}{l}\text { - I can answer yes/no questions about my } \\
\text { project } \\
\text { - I can name the objects in my project } \\
\text { - I can repeat words/short phrases about } \\
\text { my project }\end{array}$ & $\begin{array}{l}\text { - I can describe what is in my project } \\
\text { - I can use general and some specific } \\
\text { language to talk about what "Home" } \\
\text { means in my project } \\
\text { - I can list the steps to complete my } \\
\text { project }\end{array}$ & $\begin{array}{l}\text { - I can use technical language to talk } \\
\text { about the things that represent } \\
\text { "Home" to me } \\
\text { - I can explain the meaning of "Home" } \\
\text { and defend my understanding of } \\
\text { "Home" by using outside } \\
\text { information/evidence }\end{array}$ \\
\hline
\end{tabular}




\section{Appendix C: Written Component Student Assessment [Written Component PBL]}

\begin{tabular}{|c|c|c|c|c|c|c|}
\hline $\begin{array}{l}\text { Language } \\
\text { Function }\end{array}$ & $\begin{array}{l}\text { Entering } \\
\text { (Level 1) }\end{array}$ & $\begin{array}{c}\text { Emerging } \\
\text { (Level 2) }\end{array}$ & $\begin{array}{c}\text { Developing } \\
\text { (Level 3) }\end{array}$ & $\begin{array}{c}\text { Expanding } \\
\text { (Level 4) }\end{array}$ & $\begin{array}{l}\text { Bridging } \\
\text { (Level 5) }\end{array}$ & $\begin{array}{l}\text { Reaching } \\
\text { (Level 6) }\end{array}$ \\
\hline Recount & $\begin{array}{l}\text { - Writing includes } \\
\text { content } \\
\text { words/phrases } \\
\text { relating to "home" } \\
\text { - Included images, } \\
\text { diagrams, charts to } \\
\text { add details to the } \\
\text { meaning of "home" }\end{array}$ & $\begin{array}{l}\text { - Writing follows patterns } \\
\text { specific to the genre } \\
\text { chosen to represent/reflect } \\
\text { upon "home" (e.g., } \\
\text { orientation, presentation of } \\
\text { events, conclusion) } \\
\text { - Writing uses linking and } \\
\text { sequencing words and } \\
\text { phrases }\end{array}$ & $\begin{array}{l}\text { - Writing summarizes } \\
\text { content-related material } \\
\text { • Writing includes } \\
\text { important information } \\
\text { and related details to } \\
\text { explain how the project } \\
\text { represents "home" }\end{array}$ & $\begin{array}{l}\text { - Writing connects main } \\
\text { points, events, and central } \\
\text { ideas to a clear conclusion } \\
\text { about the meaning of } \\
\text { "home" }\end{array}$ & $\begin{array}{l}\cdot \text { Information is } \\
\text { coherent and organized } \\
\text { to present a clear } \\
\text { understanding of } \\
\text { "home" }\end{array}$ & $\begin{array}{l}\text { - Writing integrates } \\
\text { outside materials or } \\
\text { multiple and diverse } \\
\text { perspectives on "home" }\end{array}$ \\
\hline Explanation & $\begin{array}{l}\text { - Writing includes } \\
\text { short (provided) } \\
\text { phrases, labelled } \\
\text { charts, graphs, } \\
\text { illustrations to } \\
\text { describe "home" }\end{array}$ & $\begin{array}{l}\text { - Writing includes Using } \\
\text { transitions and connectors } \\
\text { to show causal } \\
\text { relationships or } \\
\text { procedures } \\
\text { • Writing uses everyday or } \\
\text { technical language to } \\
\text { describe "home" }\end{array}$ & $\begin{array}{l}\text { - Words and phrases } \\
\text { provide precise details, } \\
\text { descriptions, and/or } \\
\text { comparisons that } \\
\text { provide details for } \\
\text { understanding "home" } \\
\text { - Writing includes } \\
\text { genre-appropriate } \\
\text { organizational features } \\
\text { (i.e., headings, } \\
\text { introductory statements, } \\
\text { etc.) to organize text }\end{array}$ & $\begin{array}{l}\text { - Reflective or } \\
\text { explanatory writing is } \\
\text { informationally, } \\
\text { objectively presented } \\
\text { through a neutral tone } \\
\text { appropriate to the content } \\
\text { area } \\
\text { - Creative writing is } \\
\text { presented in a tone } \\
\text { appropriate to the genre } \\
\text { - Writing includes } \\
\text { images, diagrams, } \\
\text { formulas, or charts to } \\
\text { describe "home" }\end{array}$ & $\begin{array}{l}\text { - Writing combines } \\
\text { information and details } \\
\text { about "home" from a } \\
\text { variety of } \\
\text { sources/perspectives } \\
\text { - Information is } \\
\text { arranged logically and } \\
\text { cohesively }\end{array}$ & $\begin{array}{l}\text { - Writing includes } \\
\text { extended descriptions and } \\
\text { facts, details and/or } \\
\text { perspectives appropriate } \\
\text { for the writing genre to } \\
\text { develop an extended idea } \\
\text { about "home" }\end{array}$ \\
\hline Argument & $\begin{array}{l}- \text { Words and } \\
\text { phrases are } \\
\text { intentionally } \\
\text { chosen to represent } \\
\text { a specific, unified } \\
\text { point of view about } \\
\text { "home" }\end{array}$ & $\begin{array}{l}\text { - The writing's claim } \\
\text { about "home" includes } \\
\text { multiple forms of support }\end{array}$ & $\begin{array}{l}\text { - The writing's claim } \\
\text { about "home" is } \\
\text { explained through } \\
\text { reasons or evidence }\end{array}$ & $\begin{array}{l}\text { - The writing } \\
\text { demonstrates awareness } \\
\text { of the purpose and } \\
\text { intended audience } \\
\text { through word choice, } \\
\text { tone, etc. }\end{array}$ & $\begin{array}{l}\text { - Information about } \\
\text { "home" is presented in a } \\
\text { logical and organized } \\
\text { manner } \\
\text { - The writing integrates } \\
\text { multiple perspectives } \\
\text { and evidence from a } \\
\text { variety of sources to } \\
\text { synthesize a unified } \\
\text { vision of "home" }\end{array}$ & $\begin{array}{l}\text { - The writing } \\
\text { demonstrates awareness of } \\
\text { varied social, historical or } \\
\text { cultural perspectives on } \\
\text { the aspect of "home" } \\
\text { explored through the } \\
\text { project } \\
\text { - Information about } \\
\text { contrasting views are } \\
\text { presented logically and } \\
\text { coherently }\end{array}$ \\
\hline
\end{tabular}

ITJ, 2019 Volume 16, Number 1 